\title{
THE COST INFORMATION RELEVANCE IN THE DECISION FOUNDATION
}

\author{
Sorina Simona Bumbescu ${ }^{1}$ \\ Liliana Paschia $(\text { Dincă })^{2}$
}

\begin{abstract}
In this paper is realized an overview of the existing interdependence between the decision efficiency and the cost information quality who are provided to the organization management. Based on the previous studies regarding the costs and managerial decisions, in this article is developed an lapidary theoretical framework regarding the cost-general framework, the costs needed for the decisions making, the usefulness and importance of cost information system for decision process, and ultimately is presented in a lapidary form the costs structure of the European projects.
\end{abstract}

Keywords: cost; informational system; decisions; efficiency; European projects

JEL Codes: M21; M40

\section{Introduction}

The cost information system is oriented toward providing information with a detailed high level, which supports the planning, control and decisions making, focusing on the products, activities and functions cost. The decision process is an action that takes place at all the organization levels, covering the short term and long term perspective. The plans are activated by the decision, so that to a large number of decisions is needed a financial or quantitative analysis, so as to reach to express rational conclusions. For these reasons, the managerial accounting practice is deeply involved in decision process.

The complexity of the economic activity it determinates the increasing role of the financialeconomic information in the decision making. The decision quality and implicitly the predicted results of the organization depends on the information quality.

In our days, the cost analysis doesn't refers only to the knowledge of the products cost, and is oriented to the organization economic resource management, to achieve the best balance between the expenses and the obtained utilities. This means to take good decisions in all areas that has influence on the organization resource and costs.

The managerial decision should be based on relevant costs who are recognized by their forecasting characteristics who contains hidden costs, social costs and external costs

The research methodology used in the article is considering, especially, the qualitative research. It is realized a theoretical presentation of the current state of knowledge, identifying the importance of costs for the decisional process and the necessary framework for the optimal decisions. In order to capture the interactions between the different elements, it were analyze different dates, aiming the clear highlight of the costs importance for the efficiently decision making.

\footnotetext{
1 “1 Decembrie 1918” University, Alba Iulia, Romania, e-mail:sorina.bumbescu@yahoo.com 2 “1 Decembrie 1918” University, Alba Iulia, Romania, e-mail:paschialiliana@.com
} 


\section{General considerations on costs}

The cost is a simple notion that we all commonly used, and this is the reason that we believe that we know the significance. In reality there is not a cost, there are more costs and the exactly determination of a cost involves rigor, reasoning and appropriate vocabulary. It is important to make a clear distinction between the notion of cost and expense.

In the monetary expression the cost can be defined as an amount of money spent for the producing or purchasing a good, performance a work, provide a service etc. The cost can be also seen from a different perspective, so that the stress, job dissatisfaction, the noise, etc. involves psychiatric costs that affect the individual performance, and that can hardly be measured in money. A definition of the costs, seen only for a financial perspective can be considered as limitative, therefore the definition framework should be broadened to all what is necessary in order to produce or achieve a good or service.

If we refer to the organization products, the cost should be characterized not only through the resource consumption, but also by its link with the achievement. Therefore, the cost of a product, good or service can be defined as being the sum of the expenses made by the organization for obtaining and selling it; the use of production factors in the process of obtaining goods and services generates expenses which combined after different criteria forms the costs which in turn must be covered by revenues from sales.

On the other hand, the notion of "cost" is used to measure the efforts required in realization a product or service, but in reality there is not a cost for a product or service and there are only goods or services, and those involves different costs.

Because the costs reflect all the activity of the organization, the cost calculation should be considered as a management method- management by costs-with management by objectives, budgets etc.

In managerial accounting, the cost category is used for different purposes. The logic is generated by the fact that there are a lot of types of costs and these costs are grouped according to management needs (Cristea H., 2003).

Cost management - means more than measuring and reporting the costs. It is a philosophy, an attitude, a set of techniques to create more value at a lower cost (Hilton, RH, Maher, MW, Selto, FS, 2003). Is a set of techniques for calculating the cost that significantly contribute to decisionmaking, to the achievement of aims and the organization activities.

\section{The costs associated to the managerial decision making}

In a general sense, the decision represent the process conclusion through is made a choice between two or more alternatives in order to achieve one or more objectives. The decision making, regardless of the situation involved, can be considered as a general process who consists of the following steps:

- defining the objectives as a result of an initial assessment of the constraints and limitations;

- seeking the alternative measures of action from which is chosen the final decision. In this process it is important to have an efficient informational system who select the information from internal and external sources in order to avoid losing of some opportunities;

- the evaluation of alternatives consists of the realization of comparisons between the existing alternatives, so that to the decision maker to be provide a documented information in order to take an optimal decision;

- to take the decision to act, the stage in which is selected an alternative.

The managerial decisions are justified, in general, on the cost information who are considered relevant. In other words, providing coherent, complete, relevant information and in proper form is an important point in the decision making.

It is important to make a difference between a good decision and a good outcome, because one can exist without the other and vice versa. The reasoning under the incertitude conditions does 
not guarantee that we'll get the best result. The decision is taken based on information available at the time of making it, and a good decision means the maximum protection against the adverse outcomes.

In practice, the managers do not faced with one decision and the information system provides a wide range of information. Therefore, the approach should focus on the collective effect of the decisions for an organization. Therefore, choosing an information system depends on the specific decision. Specifically, it depends on the existing information, the implemented decision tree, the cost of the informational system and the optimal condition followed by the one who decide.

Besides the cost information, an important factor in the decision making is the decision maker's attitude towards the risk, because his attitudine varies from the risk seeking to risk adversity. Different decision makers may take different decisions even if they have the same information.

An important role in the alternative evaluation is the one who refers to the risk and uncertainty assessment. The decisions under uncertainty is a vitally important factor in the work of a manager. For example, there is the possibility that for various reasons the estimated cost of a project of 75,000 euro who refers to the modernization a farm to rise in reality to 8500 euro. A good manager should be able to act promptly under the uncertainty conditions, and for this he needs a decision model.

A presentation of a decision model under the uncertainty conditions is shown in figure nr. 1

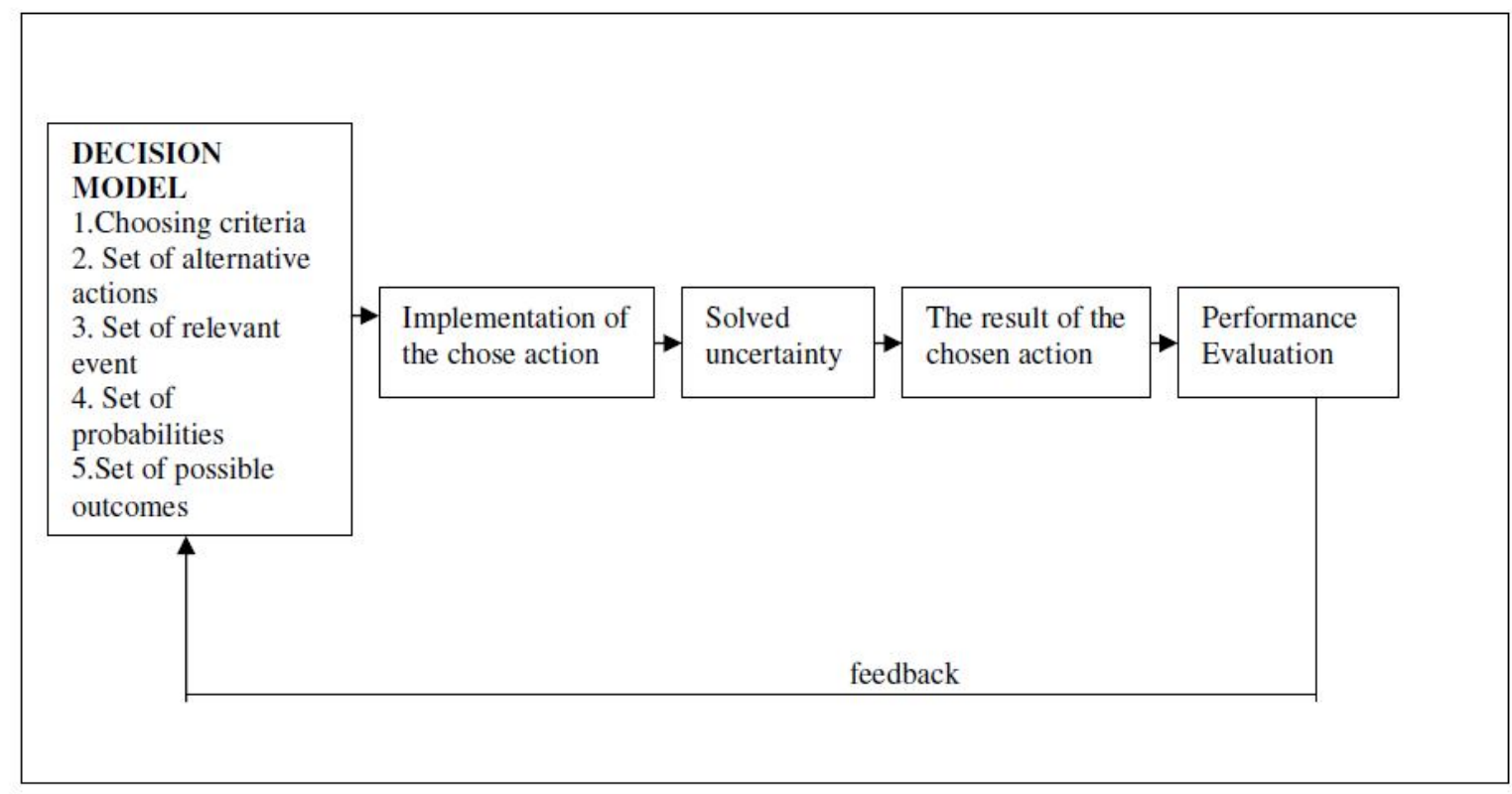

Figure no. 1. - Decision model under the uncertainty conditions

(Source: Horngren, C.T., Foster, G., 1991:648)

The management accounting tries to provide to the managers the necessary information to take decisions in full knowledge of the facts. In order to assess the different projects: the manufacture interruption of a product, the replacement of the existing equipment, the implementation of a new product etc., are made special studies in order to determine the relevant costs and revenues (some authors call them marginal costs and revenues).

The development of the decisional process involves the consumption of the human, material and information resource. From this point of view, the decision-making is similar with the production of goods and services, it needs certain costs and its implementation brings to the 
organization profits or losses. In the decisional process, the managers must take into account those costs who are relevant for the choice of an option.

The decisional process differs in terms of complexity and execution duration. From this point of view, the costs involved in the decisional process development can be determined depending on the decisional process characteristics. Thus, while in the large companies there is the possibility of division the managerial activities, in small companies the most managerial decisions are taking by a single manager. Therefore, the decentralization of decision-making in the large companies will be benefic for the increases of the management efficiency, resulting largely eliminating the distortions and delays in sending / receiving information in various departments of the companies.

Regarding the development period of the decisional process, the cost analysis must be performed separately. So, the long-term cost analysis involves the study of costs evolution on a time horizon in which all production factors are variable, while the short-term cost analysis involves the study of cost behavior on a time horizon in which some production factors are fixed (Maracine, V. et al., 1998).

\section{The cost information utility in the decision making}

The knowledge of costs represent an important factor for the decision making or for planing activities. The cost analysis of past activities is an important part of the cost accounting but managers are particularly concerned with possible future costs, which constitute the starting point for decisions regarding supply and production, pricing policy, etc

In essence, the role of cost information system consists of "the establishment of budgets, standard costs and actual costs of operations, processes, activities or products and employees analysis, profitability or use of funds" (Lucey, T. et al., 1993).

The cost information system is an important component of financial accounting information system of an organization. In table.1 are illustrated a range of information and their possible uses by the organization management.

Tabel no. 1.

Cost informational system and their possibles uses in the organisations

\begin{tabular}{|c|l|l|l|}
\hline No. & \multicolumn{1}{|c|}{$\begin{array}{c}\text { Information provided by the costs } \\
\text { informational system }\end{array}$} & \multicolumn{1}{|c|}{ The posibilities of use those information by the managers } \\
\hline 1 & The unit cost of a product, work, service & $\begin{array}{l}\text { Decisions on fixing the selling price, production planning } \\
\text { and cost control } \\
\text { Decisions regarding the purchase, manufacture or abandon } \\
\text { a product } \\
\text { Decisions about the management of product portofolilui } \\
\text { Evaluation and management performance }\end{array}$ \\
\hline 2 & $\begin{array}{l}\text { The runung cost of a departament } \\
\text { palary costs for a lor of products or for a } \\
\text { period }\end{array}$ & $\begin{array}{l}\text { The volume of low-quality goods and } \\
\text { technological losses }\end{array}$ & $\begin{array}{l}\text { Decisions regarding the organizational structure, improve } \\
\text { the production process and activities control }\end{array}$ \\
\hline 5 & $\begin{array}{l}\text { The costs behaivour according to the } \\
\text { activity level }\end{array}$ & $\begin{array}{l}\text { Production planning, salaris policys } \\
\bullet\end{array}$ & $\begin{array}{l}\text { Profit estimation and cost control } \\
\text { Decisions on the ways of increassing the organisation } \\
\text { performance }\end{array}$ \\
\hline 6 & $\begin{array}{l}\text { The cost analisis } \\
\text { Decisions on cost reduction } \\
\text { Decisions about the products and } \\
\text { management } \\
\text { Decisions on ways to increase the performance } \\
\text { Evaluation of the impact of the measures taken, expected } \\
\text { on the costs }\end{array}$ \\
\hline
\end{tabular}

(Source:Cristea, H., $2003: 125$ ) 
The cost information is important for the managers for of the following three reasons:

- based on costs it is decided the acquisition, production or abandon a product;

- the costs can be a basis for the price estabilishment;

- through the costs it is identified the needs for improvement of the products or services. In order to take a good decisions there are important four information regarding the costs:

- What costs are influenced by the decision who must be taken?

- At what is giving up if is chosen an alternativ over another?

- How will behave the costs that involves the options after the decision making?

- How it can be act on them?

The investment decisions involvs the allocation of financial and economic resources, in the hope of economic and social benefits who are uncertain. This proces of decision-making includes a comparison between the of cash outflows (costs) and cash inflows (benefits) generated by a project. In this regard, the costs are a variable key included in the cash flow forecast. The costs can be described as intentional or unintentional negative effects of a project; also the investments are parts of a project.

\section{A review of the costs used in the European projects financed by FEDR and FC}

The estimated project cost can be achieved by taking into account a pessimistic or an optimistic situation. Considering this aspect it is important to be made a sensitivity analysis, which indicate the way in which the final net figure of the benefits changes if the costs incres or decrese with a certain percentage. The increased costs arise during the process of decision making. This uncertainty should be considered in the project evaluation through the risk analysis.

In the cost-benefit analysis of EU projects are taken into account two important types of costs: capital costs and operating costs.

\section{Investment costs}

The investment costs can be considered as the capital cost incurred in connection with the project construction and which includes all expenses related to the acquisition or production of goods and the costs related to the working capital changing, representing the current assets who needs to be funded.

The initial cost of the project is independent of the funding source or eligibility criterias, referring to economic and technical resources involved in the project. follows:

Depending on the time estabilished for a project, the investment costs are classified as

- fixed assets (land, buildings, equipment, maintenance extraordinary expenses);

- comissioning costs-start-up- (licenses, patents, and other pre-production expenses);

- changes in working capital, defined as the difference between net working capital of the curent year and net working capital of the past year.

A special category of costs are the costs of reinvestment (or costs regarding the purchase of new equipment in order to replace old assets during the operations period) and the extraordinary maintenance costs, which occur occasionally in the reference period. 


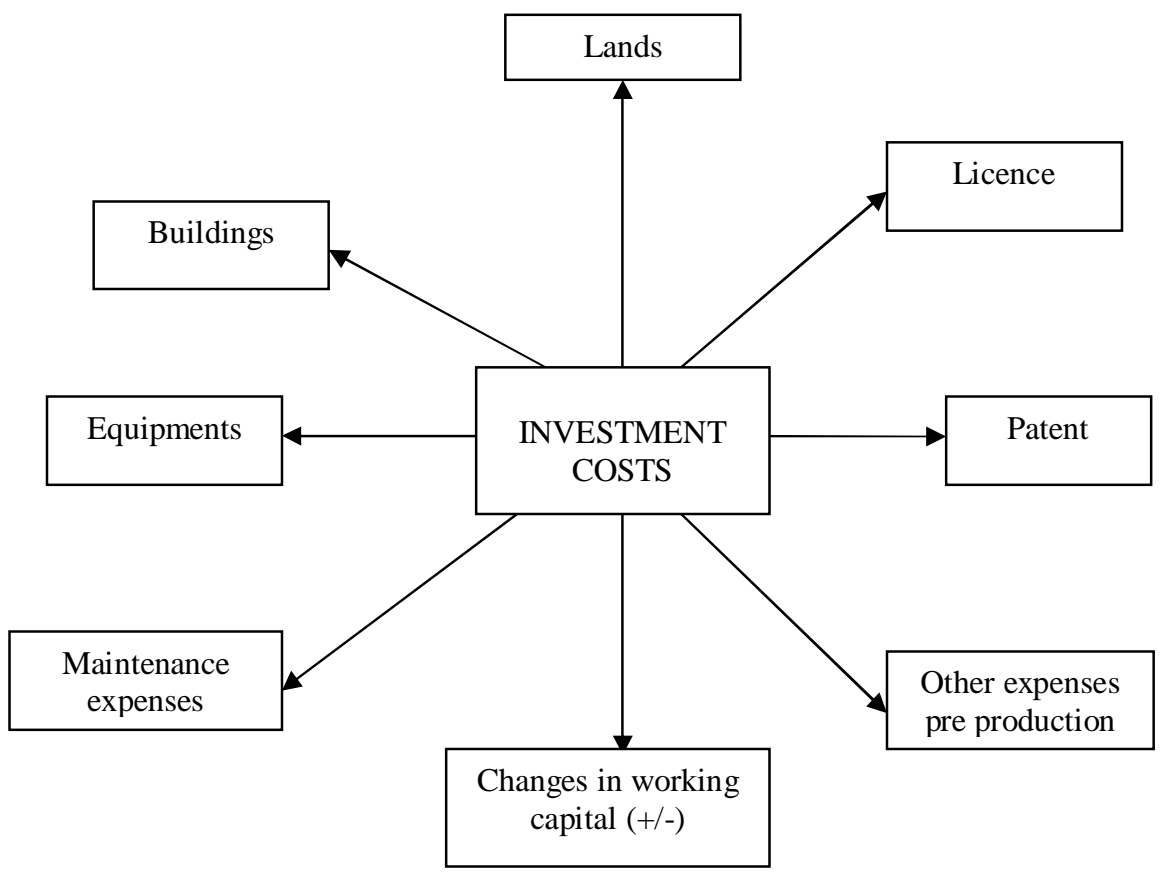

Figure no. 2. - Investment costs structure on the euprpean projects

Source:(Guide to cost-benefit analysis of investment projects, European Comision 2008:98)

\section{Operating costs}

These are the costs incurred during the investment operation, including the maintenance cost, but excluding the depreciation costs and capital cost. The operating costs refers to the purchase of goods (which are not considered investments because they have a lifetime less than 1 year) and services. The main categories of operating costs are:

- direct production costs (materials and services, personnel, maintenance, general manufacturing costs);

- general and administrative costs;

- selling and distribution costs.

Regarding the cost categories should be emphasized the difference between variable costs and fixed costs. The variable costs are those that change its value depending on the volume of production. This category includes the cost of materials, salaries for the direct manufacturing staff, energy, fuel and services for the production of goods and services, part of the maintenance costs of the equipment and infrastructure.

The fixed costs appears even if there are no longer produced goods or services. This category includes: part of the maintenance cost even if the the equipments aren't used, costs with the administrative staff and indirect production staff, materials and services needed even when not business activities are carried out.

After completing an investment, it is recommended to be done an audit who provides to the management the feedback on the obtained results, so it can be compared the actual results with the expected costs and benefits. In this case, the management should investigate to determine whether this result was recorded because the initial estimations were too optimistics or because there were problems in project implementation.

The strategy of a company is the source of its strategic decisions regarding the budgeting of the expenditures capital. The strategy who represent the base for a capital investment decision involves the implementation of high technology. In general, the decision to initiate and carry out a major project (by european funds, equity or loans) with significant effects on the organization, it is 
a strategic decision, and for this reason it is recommended to perform a rigorous assessment of the available alternatives and the effects generated on the organization.

\section{Conclusions}

In the current context of economic development, we consider as relevant and appropriate the realisation of an overview regarding the cost information utility in the decision-making. Regardless of the activity sector, to make a based decisions influences the activity of the whole organization. It's proved that the cost information is an important element for the manager's activity in the decisional process development. In the process decision, in addition to the cost information, an important role is represented by the attitude beside the risk; any decision involves a certain grade of risk.

The costs are a real tool of the management, due to their forecasting characteristics, beeing a fundamental element in taking some efficient decisions. For the managers of the organizations, the future is what matters and this should be seen as a step towards the future.

\section{References}

1. Boghean Florin, 2008, Managementul costurilor, curs

2. Briciu Sorin, 2006, Contabilitate managerial. Aspecte teoretice si practice, Editura Economica, Bucuresti

3. Cokins Gary, Sorinel Căpuşneanu, Sorin Briciu, 2012, Accounting's shift to decision-based costing, Economie teoretica si aplicata-ECTAP, volum XIX, nr. 11(576), pp. 28-42

4. Cristea Horia, 2003, Contabilitatea si calculatiile in conducerea intreprinderii, Editia a II-a, Editura CECCAR, Bucuresti

5. Hilton, R.H., Maher, M.W., Selto, F.S.,2003, Cost Management-Strategies for Busines Decision, McGraw Hill Irwin

6. Horngren, C.T., Foster, G., 1991, Cost Accounting, A Managerial Emphasis, 7th edition, Prentice Hall, 1991

7. Lucey, T., Costing, 4th edition, DP Publishing, Londra, 1993, p.1

8. Maracine, V., 1998, Decizii manageriale, Editura Economica, Bucuresti

9. Robert F. Meigs, Mary A. Meigs, Mark Bettner, Ray Whittington, 1981, Accounting: The basis for business decisions, Editura: McGraw-Hill Book Company

10. http://www.fonduri-ue.ro/res/filepicker_users/cd25a597fd-

62/Documente_Suport/Studii/0_Studii_Instrumente_Structurale/Pag.3_ACB/11_Costuri_A CB.pdf 